\title{
Prediction of staging with preoperative parameters and frozen/section in patients with a preoperative diagnosis of grade 1 endometrioid tumor in endometrial cancer
}

\author{
Alper Karalok ${ }^{1}$, Işın Üreyen ${ }^{1}$, Yıldız Reis ${ }^{1}$, Özge Oktay', Taner Turan' ${ }^{1}$, Nurettin Boran ${ }^{1}$, Dilek Bülbül², \\ Gökhan Tulunay ${ }^{1}$, Mehmet Faruk Köse ${ }^{1}$ \\ 'Division of Gynecologic Oncology, Etlik Zübeyde Hanim Women's Health Training and Research Hospital, Ankara, Turkey \\ ${ }^{2}$ Department of Pathology, Etlik Zübeyde Hanım Women's Health Training and Research Hospital, Ankara, Turkey
}

\section{Abstract}

Objective: To investigate the likelihood of the detection of the necessity of staging preoperatively with the use of clinical parameters and frozen/ section (FS).

Material and Methods: 219 patients were included who were operated on between 1996 and 2010 with a diagnosis of grade 1 endometrioid adenocarcinoma in probe curettage.

Results: Among the clinical characteristics, only age and body mass index (BMI) predicted staging preoperatively. The probability of staging increased as age increased and BMI decreased. The concordance between preoperative diagnosis and FS was $89.5 \%$. The diagnosis was upgraded at postoperative evaluation for 13 patients (5.9\%), and downgraded for 2 patients ( $0.9 \%)$ compared with FS. The wrong diagnosis regarding grade, the depth of myometrial invasion DMI, tumour type and cervical invasion in FS was clinically significant and affected the decision of staging in 10 patients. In conclusion, only 7 patients (3.2\%) who acquired staging surgery were missed in FS.

Conclusion: It was shown that preoperative clinical parameters could not effectively predict the patients who should be staged. FS predicted the lymphatic involvement with high accuracy. The patient with a preoperative diagnosis of grade 1 endometrium cancer should be operated upon in centres where FS is utilised and oncologic staging surgery can be performed. (J Turk Ger Gynecol Assoc 2014; 15: 41-8)

Key words: Endometrial cancer, body mass index, age, frozen/section, staging

Received: 19 July, 2013

Accepted: 20 September, 2013

Available Online Date: 30 January, 2014

\section{Introduction}

Endometrium cancer is usually diagnosed at an early stage (1). It is still controversial whether routine lymphadenectomy should be involved in surgical staging of this tumour that has been staged surgically in accordance with the guidelines of FIGO (International Federation of Gynecology and Obstetrics) since 1988. Some authors suggested routine lymphadenectomy in order to define lymphatic spread and to improve survival $(2,3)$. Nevertheless, it was shown that lymphadenectomy in addition to total abdominal hysterectomy and bilateral salpingo-oophorectomy in patients with early stage endometrium cancer did not improve survival $(4,5)$. Additionally, pelvic and para-aortic lymphadenectomy increases surgical morbidity $(6,7)$. Therefore, it is clear that performing lymphadenectomy for all of the patients with endometrium cancer will cause overtreatment and an increase in morbidity.
Determination of the risk factors that may indicate lymphatic spread in endometrium cancer and performing lymphadenectomy for patients with these risk factors will be an appropriate option. These risk factors are tumour type, cervical involvement, grade and depth of myometrial invasion (DMI) (8-12). These factors could be defined intraoperatively with frozen/section (FS). Preoperatively, age, body mass index (BMI), serum Ca-125, haemoglobin and platelet levels could be utilised as risk factors for lymphatic metastasis.

Age is associated with advanced disease and lymphatic metastasis $(13,14)$. An increase in BMI is associated with lower grades. However, it is difficult to say that greater BMI is associated with lower nodal metastasis rates (15). Preoperative high Ca-125 level is an independent risk factor nodal spread (16-18). In addition, preoperative lower haemoglobin level is associated with nodal metastasis and therefore with advanced disease and worse survival $(19,20)$. Preoperative thrombocytosis is observed in patients with 
advanced stages; however, there are studies stating the opposite $(16,21,22)$.

The accuracy rate of grade that is detected with probe curettage in accordance with the results of paraffin blocks ranges between $36 \%-96 \%(2,23-25)$. Intraoperatively, grade could be defined with an accuracy of 58\%-98\%; with FS, according to postoperative pathology, these rates for DMI and cervical invasion are 54\%-95\% and 95\%, respectively (26-34). In contrast, others argue that FS could not predict lymphatic spread well, meaning that all patients with endometrium cancer should be staged systematically (27).

In this study, the surgical results of patients with grade 1 endometrioid endometrium cancer were evaluated. The likelihood of the detection of the necessity of staging preoperatively with the use of clinical parameters and FS were investigated.

\section{Material and Methods}

In this study, 219 patients were included who were operated on between 1996 and 2010 with a diagnosis of grade 1 endometrioid adenocarcinoma in probe curettage. The pathological specimens of the patients coming from other hospitals with a diagnosis of endometrial cancer or complex hyperplasia with atypia were evaluated again in our hospital.

Since FS was utilised in the study, the presence of myometrial invasion and the type of cervical invasion, glandular or stromal, were important factors. Therefore, patients were staged according to the 1988 FIGO criteria. Nevertheless, stages of the patients in the study group were also defined according to the 2009 FIGO criteria.

Staging surgery is performed in our clinic for patients whose frozen-section analysis reveals a tumour type other than endometrioid adenocarcinoma, grade 2 or grade 3 disease, myometrial invasion $\geq 1 / 2$, cervical invasion and tumour size greater than $2 \mathrm{~cm}$. Staging surgery involves total abdominal hysterectomy, bilateral salpingo-oophorectomy, systematic pelvic and paraaortic lymphadenectomy, cytology and omentectomy as a standard. Cytoreductive surgery was performed in addition to staging surgery in case there was macroscopic disease intraoperatively. The patients who had not been staged according to the result of FS analysis, but who were upgraded with postoperative pathology result were restaged and given adjuvant therapy (chemotherapy and/or radiotherapy), or directly given adjuvant therapy without reoperation depending on the collective decision of both the surgeon and the patient.

Bilateral pelvic lymphadenectomy was performed. This involved complete skeletonisation of all lymphatic tissue of the common, external and internal iliac vessels and obturator fossa after visualisation of the obturator nerve. The superior surgical margin of dissection for the pelvic nodes was aortic bifurcation and the anterior distal surgical margin was the circumflex iliac vein. The lymphatic tissue of the presacral region was also harvested separately. The para-aortic lymphadenectomy was performed by mobilising the paracolic peritoneum along the lateral border of the ascending and descending colon, permitting identification of the proximal ureters and high division of the ovarian vessels. This allowed visualisation of the whole ret- roperitoneum up to the superior borders of the renal veins. All lymphatic tissue was then harvested from the lateral, anterior, and medial aspects of the vena cava and aorta up to the renal veins in all patients.

In evaluation of FS, the uterus was opened and the cavity was inspected for irregularities of counter and colour. The 2-5 fullthickness slices were made through the wall of the uterus. The area of deepest myometrial invasion was selected for FS examination. If no tumour was apparent on gross examination, at least 5 random sections were performed. All of the samples were frozen at $-25^{\circ} \mathrm{C}$, were cut to $8 \mu$ in thickness and stained with haematoxylin and eosin manually. They were evaluated in terms of grade, the depth of myometrial invasion, lymphovascular space invasion and the size of the tumour.

Descriptive statistics were calculated using the Statistical Package for Social Sciences (SPSS) 17.0 package program (SPSS Inc., Chicago IL, USA). The nominal values and the differences between the ratios were evaluated with Chi-Square and ANOVA Table Test. Univariant analysis was performed using a log rank test. The cut-off for statistical significance was set at $\mathrm{p}<0.05$.

\section{Results}

The mean age of the patients was 60.1 years and ranged between 35 and 84 years. The ratio of probe curettages performed in other hospitals was $54.8 \%$ and all of these were re-evaluated in our hospital preoperatively. According to the FIGO 1988 system, 90\% of the patients had stage 1 disease. Lymph node metastasis was observed in $5 \%$ of the patients. Preoperative Ca-125 level was $9 \mathrm{IU} / \mathrm{mL}$ (range: 2-1834 IU/mL), platelet level was 261.940/mL (range: 100.000-596.000/mL), haemoglobin was 12.3 (range: $4.4-16.1 \mathrm{mg} / \mathrm{dL}$ ) and the mean value of BMI was $34.6 \mathrm{~kg} / \mathrm{m}^{2}$ (range: $18.3-57.3 \mathrm{~kg} / \mathrm{m}^{2}$ ). The BMI was below $25 \mathrm{~kg} / \mathrm{m}^{2}$ in only 7 patients. Preoperative clinical characteristics, stages and lymph node status of the patients in the study group are listed in Table 1.

Sixty-nine (31.5\%) patients were staged intraoperatively according to the criteria used in our clinic. The mean number of the pelvic and para-aortic lymph nodes removed was 39 (range: 10-81) and 10 (range: 1-24), respectively. In 11 (16\%) patients who were staged, lymph node metastasis was observed. Lymph node involvement was only in the pelvic region in 5 patients, in the para-aortic region in 2 patients and in both regions in 4 patients (Table 1). The number of lymph nodes removed in patients who had nodal involvement and those who did not were similar ( 48.2 vs. 53 , respectively, $\mathrm{p}=0.694$ ). In the patient group who had staging surgery, $22 \%$ had advanced disease (stage III-IV). However, only $1(0.7 \%)$ patient in the group of 150 patients who did not have staging surgery had advanced disease (stage IIIA) (Table 2).

Among the clinical characteristics, only age and BMI predicted staging preoperatively (Table 3 ). The probability of staging increased as age increased and BMI decreased. Staging surgery was performed for $24 \%$ of the patients whose ages were under 60 years and for $39 \%$ of the patients whose ages were above 60 years $(\mathrm{p}=0.016)$. When $34 \mathrm{~kg} / \mathrm{m}^{2}$ was accepted as 
the median BMI, $35 \%$ and $20 \%$ of the patients below and above this value were staged, respectively $(p=0.044)$. When $25 \mathrm{~kg} / \mathrm{m}^{2}$ was accepted as the boundary, these numbers were $57 \%$ and $26 \%$, respectively. Nevertheless, this difference was insignificant $(\mathrm{p}=0.074)$, even though the difference was 30\%. The reason for this was the disproportionate distribution between the groups, since only 7 patients had a BMI below $25 \mathrm{~kg} / \mathrm{m}^{2}$. When age and BMI were evaluated together, the prediction of staging preoperatively was improved. Forty-five percent of the patients with these criteria and $15 \%$ of the patients without these criteria were staged $(p=0.009)$ (Table 3$)$. By utilising these criteria, 73\% of the patients requiring staging and $62 \%$ of the patients who did not were defined, meaning that the sensitivity and specificity of these factors for staging were $73 \%$ and $62 \%$, respectively. The false positive ratio and false negative ratio were $38 \%$ and $15 \%$, respectively. Preoperative Ca-125 and haemoglobin level, platelet value and the place of the probe curettage did not predict the probability of staging.

In the FS evaluation of patients with a preoperative diagnosis of grade 1 endometrioid adenocarcinoma, 13 patients did not have a tumour and 10 patients had a grade 2 tumour (Table 2). The concordance between preoperative diagnosis and FS was $89.5 \%$. Similarly, the concordance of grade between preoperative and postoperative diagnosis and FS and postoperative diag-

Table 1. Characteristic features

\begin{tabular}{|c|c|c|c|}
\hline \multicolumn{2}{|l|}{ Parameter } & n / Mean & \% / Median (Range) \\
\hline \multicolumn{2}{|l|}{ Age (years) } & 60.1 & $60(35-84)$ \\
\hline \multirow{8}{*}{1988 FIGO Stage } & IA & 40 & 18.3 \\
\hline & IB & 141 & 64.4 \\
\hline & IC & 16 & 7.3 \\
\hline & IIA & 4 & 1.8 \\
\hline & IIB & 2 & 0.9 \\
\hline & IIIA & 5 & 2.3 \\
\hline & IIIC & 10 & 4.6 \\
\hline & IVB & 1 & 0.5 \\
\hline \multirow{7}{*}{2009 FIGO Stage } & IA & 183 & 83.6 \\
\hline & IB & 19 & 8.7 \\
\hline & II & 2 & 0.9 \\
\hline & IIIA & 4 & 1.8 \\
\hline & IIIC1 & 5 & 2.3 \\
\hline & IIIC2 & 5 & 2.3 \\
\hline & IVB & 1 & 0.5 \\
\hline \multirow{2}{*}{ Staging Surgery } & Performed & 69 & 31.5 \\
\hline & Not performed & 150 & 68.5 \\
\hline \multirow{3}{*}{ Number of removed pelvic lymph nodes } & Pelvic & 39 & $38.5(10-81)$ \\
\hline & Paraaortic & 10 & $10(1-24)$ \\
\hline & Total & 49 & $49(12-98)$ \\
\hline \multirow{2}{*}{ Lymph node metastasis } & Negative & 58 & 84 \\
\hline & Positive & 11 & 16 \\
\hline \multirow{3}{*}{ Region of metastatic lymph nodes } & Only pelvic region & 5 & 2.3 \\
\hline & Only paraaortic region & 2 & 0.9 \\
\hline & Both regions & 4 & 1.8 \\
\hline \multicolumn{2}{|l|}{ Preoperative platelet level (n/mL) } & 261.940 & $261.000(100.000-596.000)$ \\
\hline \multicolumn{2}{|l|}{ Preoperative haemoglobin level (mg/dL) } & 12.3 & $12.7(4.4-16.1)$ \\
\hline \multicolumn{2}{|l|}{ Preoperative body mass index $\left(\mathrm{kg} / \mathrm{m}^{2}\right)$} & 34.6 & $34(18.3-57.3)$ \\
\hline \multicolumn{2}{|l|}{ Preoperative Ca-125 level (IU/mL) } & 55.6 & $9(2-1834)$ \\
\hline \multirow[t]{2}{*}{ Place of probe curettage } & Our centre & 99 & 45.2 \\
\hline & Other centre & 120 & 54.8 \\
\hline
\end{tabular}


nosis was $92.7 \%$ and $93.2 \%$, respectively (Table 4). The diagnosis was upgraded at postoperative evaluation for 13 patients (5.9\%), and was downgraded for 2 patients (0.9\%) compared with FS. This change was clinically significant for only 3 of the 13 upgraded patients. These 3 patients were stated to have a grade 1 tumour intraoperatively and reported to have grade 2 disease in the final pathology report.

Thirty-nine patients (17.8\%) were defined to have DMI $\geq 1 / 2$ in FS and 41 patients (18.7) had DMI $\geq 1 / 2$ at postoperative examination. DMI defined postoperatively was similar to FS in 188 (85.8\%) patients (Table 5). However, DMI was underestimated in 21 patients (9.6\%) and overestimated in 10 patients (4.6\%). Nevertheless, this discordance was clinically significant only in 5 patients who had a $\mathrm{DMI}<1 / 2$ in $\mathrm{FS}$ and $\mathrm{DMI} \geq 1 / 2$ at postoperative evaluation. The concordance of DMI between the FS and postoperative pathology was not affected by the preoperative clinical parameters (Table 5).
In the study population, any tumour other than endometrioidtype was not defined in the intraoperative examination, while clear cell tumour in 1 patient and mixed-type tumour in one patient were diagnosed at postoperative evaluation (Table 6). These 2 patients were stated to have endometrioid tumour intraoperatively and were not staged.

Cervical invasion could not be defined in FS in 4 patients. Invasion was glandular in 2 patients who did not have high risk surgical factors. These 2 patients were reported to have stage IB disease according to the FIGO 2009 criteria. The other 2 patients had stromal invasion, which was clinically significant.

The wrong diagnoses regarding grade, DMI, tumour type and cervical invasion in FS were clinically significant and affected the decision of staging in 10 patients. In 2 patients, more than one parameter was wrongly defined. Three of these 10 patients were staged because of the existence of other high risk factors. The first patient who was staged had grade 1 disease and DMI $\geq 1 / 2$.

Table 2. Stages of the patients

\begin{tabular}{|c|c|c|c|c|c|c|c|c|}
\hline \multirow[b]{2}{*}{ Staging Surgery } & \multicolumn{8}{|c|}{1988 FIGO Stage } \\
\hline & IA & IB & IC & IIA & IIB & IIIA & IIIC & IVB \\
\hline Performed, n (\%) & - & $37(53.6)$ & $14(20.3)$ & $2(2.9)$ & $1(1.4)$ & $4(5.8)$ & $10(14.5)$ & $1(1.4)$ \\
\hline
\end{tabular}

Table 3. Clinical parameters determining the probability of staging preoperatively

\begin{tabular}{|c|c|c|c|c|}
\hline \multirow{2}{*}{\multicolumn{2}{|c|}{ Parameter }} & \multicolumn{2}{|c|}{ Staging Surgery (\%) } & \multirow[b]{2}{*}{$\mathbf{p}$} \\
\hline & & \multirow{2}{*}{$\begin{array}{c}\text { Performed } \\
24 \\
\end{array}$} & \multirow{2}{*}{$\begin{array}{c}\text { Not Performed } \\
76 \\
\end{array}$} & \\
\hline Age $^{1}$ & $<60$ & & & \multirow{2}{*}{0.016} \\
\hline & $\geq 60$ & 39 & 61 & \\
\hline \multirow[t]{2}{*}{ Preoperative platelet level $(\mathrm{n} / \mathrm{mL})$} & $\leq 400.000$ & 33 & 67 & \multirow{2}{*}{0.269} \\
\hline & $>400.000$ & 50 & 50 & \\
\hline \multirow[t]{2}{*}{ Preoperative platelet level $(\mathrm{n} / \mathrm{mL})^{1}$} & $<261.000$ & 33 & 67 & \multirow{2}{*}{0.690} \\
\hline & $\geq 261.000$ & 36 & 64 & \\
\hline \multirow[t]{2}{*}{ Preoperative haemoglobin level $(\mathrm{mg} / \mathrm{dL})^{1}$} & $\leq 12$ & 40 & 60 & \multirow{2}{*}{0.247} \\
\hline & $>12$ & 31 & 69 & \\
\hline \multirow[t]{2}{*}{ Body mass index $\left(\mathrm{kg} / \mathrm{m}^{2}\right)$} & $<25$ & 57 & 43 & \multirow{2}{*}{0.073} \\
\hline & $\geq 25$ & 26 & 74 & \\
\hline \multirow[t]{2}{*}{ Body mass index $\left(\mathrm{kg} / \mathrm{m}^{2}\right)^{1}$} & $<34$ & 35 & 65 & \multirow{2}{*}{0.044} \\
\hline & $\geq 34$ & 20 & 80 & \\
\hline \multirow[t]{2}{*}{ Age and body mass index } & $<60$ and $\geq 34$ & 15 & 85 & \multirow{2}{*}{0.009} \\
\hline & $\geq 60$ and $<34$ & 45 & 55 & \\
\hline \multirow[t]{2}{*}{ Preoperative Ca-125 level (IU/mL) } & $<35$ & 28 & 72 & \multirow{2}{*}{0.178} \\
\hline & $\geq 35$ & 50 & 50 & \\
\hline \multirow[t]{2}{*}{ Preoperative Ca-125 level (IU/mL) ${ }^{1}$} & $<9$ & 36 & 64 & \multirow{2}{*}{0.616} \\
\hline & $\geq 9$ & 29 & 71 & \\
\hline \multirow[t]{2}{*}{ Place of probe curettage } & Our centre & 32 & 68 & \multirow{2}{*}{0.794} \\
\hline & Other centre & 31 & 69 & \\
\hline
\end{tabular}


Table 4. Concordance of grade and depth of myometrial invasion between intraoperative and postoperative pathologies

\begin{tabular}{|c|c|c|c|}
\hline \multirow[b]{2}{*}{ Intraoperative } & \multicolumn{3}{|c|}{ Postoperative } \\
\hline & \multicolumn{3}{|c|}{ Grade } \\
\hline Grade & No malignancy & Grade 1 & Grade 2 \\
\hline No malignancy, n (\%) & $3(23.1 \%)$ & $10(76.9 \%)$ & - \\
\hline Grade 1, n (\%) & $1(0.5 \%)$ & $192(98 \%)$ & $3(1.5 \%)$ \\
\hline Grade $2, \mathrm{n}(\%)$ & - & $1(10 \%)$ & $9(90 \%)$ \\
\hline \multirow[b]{2}{*}{$\begin{array}{l}\text { Depth of myometrial } \\
\text { invasion }\end{array}$} & \multicolumn{3}{|c|}{ Depth of myometrial invasion } \\
\hline & $\begin{array}{l}\text { No malignancy } \\
\text { and invasion }\end{array}$ & $<1 / 2$ & $\geq 1 / 2$ \\
\hline $\begin{array}{l}\text { No malignancy and } \\
\text { invasion, } \mathrm{n}(\%)\end{array}$ & $30(76.9 \%)$ & $9(23.1 \%)$ & - \\
\hline$<1 / 2, \mathrm{n}(\%)$ & $7(5 \%)$ & $129(91.5 \%)$ & $5(3.5 \%)$ \\
\hline$\geq 1 / 2, \mathrm{n}(\%)$ & $1(2.6 \%)$ & $2(5.1 \%)$ & $36(92.3 \%)$ \\
\hline
\end{tabular}

Table 5. Factors determining discordance of depth of myometrial invasion between intraoperative and postoperative pathologies

\begin{tabular}{|c|c|c|c|c|}
\hline \multirow{2}{*}{\multicolumn{2}{|c|}{ Parameter }} & \multicolumn{2}{|c|}{$\begin{array}{c}\text { Depth of } \\
\text { myometrial invasion }\end{array}$} & \multirow[b]{2}{*}{$\mathbf{p}$} \\
\hline & & \multirow{2}{*}{\begin{tabular}{|c|} 
Concordance \\
82 \\
\end{tabular}} & \multirow{3}{*}{\begin{tabular}{|c|} 
Discordance \\
18 \\
10 \\
\end{tabular}} & \\
\hline $\operatorname{Age}^{1}$ & $<60$ & & & \multirow{2}{*}{0.108} \\
\hline & $\geq 60$ & 90 & & \\
\hline \multirow{2}{*}{$\begin{array}{l}\text { Preoperative platelet } \\
\text { level }(\mathrm{n} / \mathrm{mL})\end{array}$} & $\leq 400.000$ & 88 & 12 & \multirow{2}{*}{0.452} \\
\hline & $>400.000$ & 80 & 20 & \\
\hline \multirow{2}{*}{$\begin{array}{l}\text { Preoperative platelet } \\
\text { level }(\mathrm{n} / \mathrm{mL})^{1}\end{array}$} & $<261.000$ & 91 & 9 & \multirow{2}{*}{0.209} \\
\hline & $\geq 261.000$ & 84 & 16 & \\
\hline \multirow{2}{*}{$\begin{array}{l}\text { Preoperative } \\
\text { haemoglobin level } \\
(\mathrm{mg} / \mathrm{dL})^{1}\end{array}$} & $\leq 12$ & 85 & 15 & \multirow[b]{2}{*}{0.364} \\
\hline & $>12$ & 90 & 10 & \\
\hline \multirow{2}{*}{$\begin{array}{l}\text { Body mass index } \\
\left(\mathrm{kg} / \mathrm{m}^{2}\right)\end{array}$} & $<25$ & 100 & - & \multirow{2}{*}{0.239} \\
\hline & $\geq 25$ & 83 & 17 & \\
\hline \multirow{2}{*}{$\begin{array}{l}\text { Body mass index } \\
\left(\mathrm{kg} / \mathrm{m}^{2}\right)^{1}\end{array}$} & $<34$ & 85 & 15 & \multirow{2}{*}{0.905} \\
\hline & $\geq 34$ & 84 & 16 & \\
\hline \multirow{2}{*}{$\begin{array}{l}\text { Preoperative Ca-125 } \\
\text { level (IU/mL) }\end{array}$} & $<35$ & 91 & 9 & \multirow{2}{*}{0.309} \\
\hline & $\geq 35$ & 84 & 16 & \\
\hline \multirow{2}{*}{$\begin{array}{l}\text { Preoperative Ca-125 } \\
\text { level }(\mathrm{IU} / \mathrm{mL})^{1}\end{array}$} & $<9$ & 89 & 11 & \multirow{2}{*}{0.576} \\
\hline & $\geq 9$ & 85 & 15 & \\
\hline
\end{tabular}

In the other 2 patients who had DMI $<1 / 2$, the reason for staging surgery was tumour size. These 2 patients were reported to have grade 1 disease intraoperatively. There was no lymph node involvement in these 3 patients. In conclusion, only 7 patients (3.2\%) who acquired staging surgery were missed by FS.

The 7 missed patients who were not staged intraoperatively according to the FS results are defined in Table 7 . In 1 of the 2 patients who were missed due to wrong tumour type in FS, the postoperative tumour type was mixed-type (Patient \#1). The tumour had both endometrioid and mucinous components and adjuvant therapy was not considered. The postoperative tumour type was clear cell in the second patient and staging surgery was chosen for this patient (Patient \#2). However, the patient rejected surgery and she was lost to follow-up. For the patient who had a wrong diagnosis with regard to DMI and grade, staging was not considered and she had adjuvant pelvic radiotherapy (Patient \#3). She died of a cause other than her tumour at the end of 60 months of follow-up without recurrence. The patient with an underestimated DMI in FS was recommended to have adjuvant pelvic radiotherapy. Nevertheless, she rejected this treatment and was lost to follow-up (Patient \#4). Another patient with underestimated DMI was defined to have stromal cervical invasion postoperatively (Patient \#5). This patient underwent staging surgery and did not have lymph node involvement. She had adjuvant pelvic radiotherapy and did not report recurrence in 46 months of follow-up. The other patient with underestimated DMI in FS had adjuvant pelvic radiotherapy and was lost to follow-up after 7 months (Patient \#6). There was no recurrence during follow-up. The last patient who was not staged due to underestimation in FS, resulting in clinically significant fault, had stage IIIA disease according to FIGO 1988 (Patient \#7). This patient had ovarian involvement. Cervical stromal metastasis was also missed, in addition to microscopic ovarian involvement in FS. This patient was not restaged and took 6 cycles of paclitaxel $\left(175 \mathrm{mg} / \mathrm{m}^{2}\right)$ + carboplatin $(\mathrm{AUC}=6)$ chemotherapy and pelvic radiotherapy following chemotherapy. There was no recurrence during 120 months of follow-up.

\section{Discussion}

An increase in BMI is associated with endometrioid histology, lower grade and lower stages, since advanced age is associated with non-endometrioid histology and advanced stages of endometrial cancer $(14,35)$. In the present study, $35 \%$ of the patients with a BMI under $34 \mathrm{~kg} / \mathrm{m}^{2}, 20 \%$ of the patients with a BMI above it, $24 \%$ of the patients whose ages were under 60 years old and $39 \%$ of the patients whose ages were above 60 were staged ( $p=0.044, p=0.016$, respectively). When both of these parameters were evaluated together, $45 \%$ of the patients who were 60 years old or older with a BMI $<34 \mathrm{~kg} / \mathrm{m}^{2}$ were staged, while $15 \%$ of the patients who were below 60 years old with a BMI $\geq 34 \mathrm{~kg} / \mathrm{m}^{2}$ were staged $(p=0.009)$. The sensitivity of these factors when used together was $73 \%$, meaning that more than $25 \%$ of the patients with high risk factors who should be staged could not be detected when preoperative clinical parameters were used. Therefore, which patients with a preoperative diagnosis of grade 1 endometrioid type tumour should be staged could not be detected by using these clinical parameters.

A high level of preoperative Ca-125 was shown to be associated with high tumour grade, advanced stages and DMI $(17,18,21,36)$. Additionally, lower levels of preoperative haemoglobin levels and thrombocytosis were associated with advanced stages and worse prognosis $(19,20,21,22)$. In the presented study, preoperative Ca-125, platelet and haemoglobin levels could not define the probability of staging. 
Table 6. Intraoperative and postoperative results of grade, depth of myometrial invasion and histopathology

\begin{tabular}{|c|c|c|c|c|}
\hline Parameter & \multicolumn{4}{|l|}{ Grade } \\
\hline Grade & \multicolumn{2}{|l|}{ No malignancy } & 1 & 2 \\
\hline Intraoperative & \multicolumn{2}{|l|}{$13(5.9 \%)$} & $196(89.5 \%)$ & $10(4.6 \%)$ \\
\hline \multirow[t]{2}{*}{ Postoperative } & \multicolumn{2}{|l|}{$4(1.8 \%)$} & $203(92.7)$ & $12(5.5)$ \\
\hline & \multicolumn{4}{|l|}{ Depth of myometrial invasion } \\
\hline Depth of myometrial invasion & No malignancy or invasion & & $<1 / 2$ & $\geq 1 / 2$ \\
\hline Intraoperative & $39(17.8 \%)$ & & $141(64.4 \%)$ & $39(17.8 \%)$ \\
\hline \multirow[t]{2}{*}{ Postoperative } & $38(17.4 \%)$ & & $140(63.9)$ & $41(18.7 \%)$ \\
\hline & \multicolumn{2}{|l|}{ Histopathology } & & \\
\hline Histopathology & No malignancy & $\mathrm{CAH}$ & Endometrioid type & Other \\
\hline Intraoperative & $7(3.2 \%)$ & $6(2.7 \%)$ & $206(94.1 \%)$ & - \\
\hline Postoperative & $3(1.4 \%)$ & $1(0.5 \%)$ & $213(97.2 \%)$ & $2(0.9 \%)$ \\
\hline
\end{tabular}

Table 7. Patients who were not staged due to faulty Frozen/Section

\begin{tabular}{|c|c|c|c|c|c|c|c|c|c|c|c|}
\hline \multirow[b]{2}{*}{$\mathbf{P t}$} & \multirow[b]{2}{*}{ Stg1 } & \multirow[b]{2}{*}{ Age } & \multicolumn{3}{|c|}{ Frozen/Section } & \multicolumn{4}{|c|}{ Postoperative histopathology } & \multirow{2}{*}{$\begin{array}{c}\text { Additional or } \\
\text { adjuvant therapy }\end{array}$} & \multirow{2}{*}{$\begin{array}{c}\text { Last } \\
\text { Status }\end{array}$} \\
\hline & & & Gr & DMI & Tumour type & $\mathbf{G r}$ & DMI & Tumour type & C $x$ in & & \\
\hline 1 & IB & 65 & 1 & $<1 / 2$ & Endometrioid & 1 & $<1 / 2$ & Mix & - & No therapy & AWOD \\
\hline 2 & IA & 66 & 1 & No invasion & Endometrioid & 1 & No invasion & Clear cell & - & Re-operation & Lost to f-up \\
\hline 3 & IC & 75 & 1 & $<1 / 2$ & Endometrioid & 2 & $\geq 1 / 2$ & Endometrioid & - & Pelvic RT & DOOD \\
\hline 4 & IB & 84 & 1 & $<1 / 2$ & Endometrioid & 2 & $<1 / 2$ & Endometrioid & - & Pelvic RT & Lost to f-up \\
\hline 5 & IIB & 43 & 1 & $<1 / 2$ & Endometrioid & 1 & $\geq 1 / 2$ & Endometrioid & + & $\begin{array}{l}\text { Re-operation } \\
\text { followed by } \\
\text { pelvic RT }\end{array}$ & AWOD \\
\hline 6 & IC & 62 & 1 & $<1 / 2$ & Endometrioid & 1 & $\geq 1 / 2$ & Endometrioid & - & Pelvic RT & Lost to f-up \\
\hline 7 & IIIA & 59 & 1 & $<1 / 2$ & Endometrioid & 1 & $\geq 1 / 2$ & Endometrioid & + & $\begin{array}{l}\text { CT followed by } \\
\text { pelvic RT }\end{array}$ & AWOD \\
\hline
\end{tabular}

As the grade of the tumour increases, the probability of lymph node involvement rises (37). Higher or lower tumour grade may be detected in the intraoperative FS according to the preoperative pathology result. There may be discordance between preoperative and postoperative pathologies. Nevertheless, intraoperative FS had a high accuracy rate (88-89\%) in determining grade $(32,38)$. In the present study, grade detected in FS was upgraded in postoperative pathology for $5.9 \%$ of patients and was downgraded for $0.9 \%$ of patients. Concordance of grade between preoperative diagnosis and FS was $89.5 \%$ and it was $92.7 \%$ between preoperative and postoperative diagnoses. In the study of Sanjuan et al. (38), concordance of grade of patients with a preoperative diagnosis of grade 1 or 2 disease with postoperative pathology was $89 \%$. However, in the study of Neubauer et al. (39), 22.5\% of the patients with a preoperative diagnosis of grade 1 endometrial cancer had a final pathology result showing a grade higher than 1 . In the study by BenShacher et al. (40), when similar factors were used for staging (grade 1 or 2 disease in addition to DMI $\geq 1 / 2$, cervical invasion, grade 3 and non-endometrioid histology), $82 \%$ of 182 patients with grade 1 disease acquired staging surgery. Additionally, the grades of $19 \%$ of these patients were upgraded in postoperative pathology, and none of them were downgraded (40).

As DMI increases, the rate of lymphatic involvement increases. DMI could be defined accurately in FS with a rate of $88-95 \%$ compared to postoperative pathology $(32,41-43)$. In the present study, patients with a preoperative diagnosis of grade 1 endometrioid tumour were evaluated and DMI was defined accurately in $85.8 \%$ of the patients according to the postoperative pathology.

In this study, when patients with a preoperative diagnosis of grade 1 endometrioid tumour were managed with FS, only $3.2 \%$ of the patients were not staged, although they should be. Additionally, FS was shown to have a high accuracy rate in detecting risk factors for lymph node metastasis. When risk factors determined in FS were used, 30\% of this group of patients were staged and $5 \%$ (n: 11/219) were found to have lymph node involvement. When Qinlivan et al. (32) used similar criteria (grade 1 or 2 disease in addition to DMI $\geq 1 / 2$, cervical invasion, grade 3 and non-endometrioid histology) for staging, $2.3 \%$ of 
patients were found to undergo suboptimal surgery according to the postoperative pathology.

Who should operate on patients with a diagnosis of endometrial cancer is controversial and has not been discussed as much as ovarian cancer. There are limited numbers of studies in the literature. It was stated that, when patients with a preoperative diagnosis of endometrial cancer were operated upon by gynaecologic oncologists, they were found to acquire postoperative adjuvant radiotherapy less often and were found to have less morbidity secondary to radiotherapy (44). In the present study, it was shown that preoperative parameters did not predict patients requiring staging accurately and that FS predicted the lymphatic involvement with high accuracy. Therefore, in all of the patients with a diagnosis of grade 1 endometrial cancer, FS should be performed and their surgery should be performed in centres with gynaecologic oncology expertise.

The retrospective nature of the study is the main limitation of this paper. However, this study was performed in a homogeneous group containing only patients with grade 1 endometrial cancer. In addition, the higher number of patients involved compared with the previous studies and the higher number of lymph nodes removed were the advantages of the present study.

In the presented study, among the selected preoperative clinical parameters, only age and BMI were found to be associated with risk factors for lymph node metastasis. However, even when both of these were evaluated together, only $45 \%$ of the patients with at least one of the risk factors determined in FS could be defined. More than 25\% of the patients with high risk factors who should be staged could not be detected when preoperative clinical parameters were used. Therefore, which patients with a preoperative diagnosis of grade 1 endometrioid type tumour should be staged could not be detected by using these clinical parameters. Patients with a preoperative diagnosis of grade 1 endometrium cancer should be operated upon in centres where FS is utilised and oncologic staging surgery could be performed.

Ethics Committee Approval: N/A

Informed Consent: N/A

Peer-review: Externally peer-reviewed.

Author contributions: Concept - T.T., A.K.; Design - I.Ü., A.K.; Supervision - M.F.K.; Resource - Y.R., Ö.O.; Materials - G.T., D.B.; Data Collection\&/or Processing - Y.R., Ö.O., T.T.; Analysis\&/or Interpretation - N.B.; Literature Search - I.Ü.; Writing - A.K., T.T.; Critical Reviews - M.F.K., G.T.

Conflict of Interest: No conflict of interest was declared by the authors.

Financial Disclosure: The authors declared that this study received no financial support.

\section{References}

1. Amant F, Moerman P, Neven P, Timmerman D, Van Limbergen E, Vergote I. Endometrial cancer. Lancet 2005; 366: 491-505 [CrossRef]

2. Frumovitz M, Singh DK, Meyer L, Smith DH, Wertheim I, Resnik E, et al. Predictors of final histology in patients with endometrial cancer. Gynecol Oncol 2004; 95: 463-8. [CrossRef]
3. Kilgore LC, Partridge EE, Alvarez RD, Austin JM, Shingleton HM, Noojin F 3rd, et al. Adenocarcinoma of the endometrium: survival comparisons of patients with and without pelvic node sampling. Gynecol Oncol 1995; 56: 29-33. [CrossRef]

4. ASTEC study group, Kitchener H, Swart AM, Qian Q, Amos C, Parmar MK. Efficacy of systematic pelvic lymphadenectomy in endometrial cancer (MRC ASTEC trial): a randomized study. Lancet 2009; 373: 125-36. [CrossRef]

5. Chan JK, Wu H, Cheung MK, Shin JY, Osann K, Kapp DS. The outcomes of 27,063 women with unstaged endometrioid uterine cancer. Gynecol Oncol 2007; 106: 282-8. [CrossRef]

6. Larson DM, Johnson K, Olson KA. Pelvic and para-aortic lymphadenectomy for surgical staging of endometrial cancer: morbidity and mortality. Obstet Gynecol 1992; 79: 998-1001

7. Hidaka T, Kato K, Yonezawa R, Shima T, Nakashima A, Nagira K, et al. Omission of lymphadenectomy is possible for low-risk corpus cancer. Eur J Surg Oncol 2007; 33: 86-90. [CrossRef]

8. Creasman WT, Morrow CP, Bundy BN, Homesley HD, Graham JE, Heller PB. Surgical pathologic spread patterns of endometrial cancer. A Gynecologic Oncology Group Study. Cancer 1987; 60: 2035-41. [CrossRef]

9. Chi DS, Barakat RR, Palayekar MJ, Levine DA, Sonoda Y, Alektiar $\mathrm{K}$, et al. The incidence of pelvic lymph node metastasis by FIGO staging for patients with adequately surgically staged endometrial adenocarcinoma of endometrioid histology. Int $\mathrm{J}$ Gynecol Cancer 2008; 18: 269-73. [CrossRef]

10. Boronow RC, Morrow CP, Creasman WT, DiSaia PJ, Silverberg SG, Miller A, et al. Surgical staging in endometrial cancer: clinical-pathologic findings of a prospective study. Obstet Gynecol 1984; 63: 825-32

11. Frei KA, Kinkel K, Bonél HM, Lu Y, Zaloudek C, Hricak H. Prediction of deep myometrial invasion in patients with endometrial cancer: clinical utility of contrast-enhanced MR imaging-a meta-analysis and Bayesian analysis. Radiology 2000; 216: 444-9. [CrossRef]

12. Zhang $\mathrm{C}$, Wang $\mathrm{C}$, Feng W. Clinicopathological risk factors for pelvic lymph node metastasis in clinical early-stage endometrioid endometrial adenocarcinoma. Int J Gynecol Cancer 2012; 22: 1373-7. [CrossRef]

13. Jolly S, Vargas CE, Kumar T, Weiner SA, Brabbins DS, Chen PY, et al. The impact of age on long-term outcome in patients with endometrial cancer treated with postoperative radiation. Gynecol Oncol 2006; 103: 87-93. [CrossRef]

14. Lachance JA, Everett EN, Greer B, Mandel L, Swisher E, Tamimi H, et al.The effect of age on clinical/pathologic features, surgical morbidity, and outcome in patients with endometrial cancer. Gynecol Oncol. 2006; 101: 470-5. [CrossRef]

15. Pavelka JC, Ben-Shachar I, Fowler JM, Ramirez NC, Copeland LJ, Eaton LA, et al. Morbid obesity and endometrial cancer: surgical, clinical, and pathologic outcomes in surgically managed patients. Gynecol Oncol 2004; 95: 588-92. [CrossRef]

16. Gücer F, Moser F, Tamussino K, Reich O, Haas J, Arikan G, et al. Thrombocytosis as a prognostic factor in endometrial carcinoma. Gynecol Oncol 1998; 70: 210-4. [CrossRef]

17. Chen YL, Huang CY, Chien TY, Huang SH, Wu CJ, Ho CM. Value of pre-operative serum $\mathrm{CA} 125$ level for prediction of prognosis in patients with endometrial cancer. Aust N Z J Obstet Gynaecol 2011; 51: 397-402. [CrossRef]

18. Chung HH, Kim JW, Park NH, Song YS, Kang SB, Lee HP. Use of preoperative serum CA-125 levels for prediction of lymph node metastasis and prognosis in endometrial cancer. Acta Obstet Gynecol Scand 2006; 85: 1501-5. [CrossRef]

19. Metindir J, Bilir Dilek G. Preoperative hemoglobin and platelet count and poor prognostic factors in patients with endometrial carcinoma. J Cancer Res Clin Oncol 2009; 135: 125-9. [CrossRef] 
20. Tamussino KF, Gücer F, Reich O, Moser F, Petru E, Scholz HS. Pretreatment hemoglobin, platelet count, and prognosis in endometrial carcinoma. Int J Gynecol Cancer 2001; 11: 236-40. [CrossRef]

21. Suh DH, Kim HS, Chung HH, Kim JW, Park NH, Song YS, et al. Pre-operative systemic inflammatory response markers in predicting lymph node metastasis in endometrioid endometrial adenocarcinoma. Eur J Obstet Gynecol Reprod Biol 2012; 162: 206-10. [CrossRef]

22. Ayhan A, Bozdag G, Taskiran C, Gultekin M, Yuce K, Kucukali T. The value of preoperative platelet count in the prediction of cervical involvement and poor prognostic variables in patients with endometrial carcinoma. Gynecol Oncol 2006; 103: 902-5. [CrossRef]

23. Sanjuán A, Cobo T, Pahisa J, Escaramís G, Ordi J, Ayuso JR, et al. Preoperative and intraoperative assessment of myometrial invasion and histologic grade in endometrial cancer: role of magnetic resonance imaging and frozen section. Int J Gynecol Cancer 2006; 16: 385-90. [CrossRef]

24. Wang X, Zhang H, Di W, Li W. Clinical factors affecting the diagnostic accuracy of assessing dilation and curettage vs. frozen section specimens for histologic grade and depth of myometrial invasion in endometrial carcinoma. Am J Obstet Gynecol 2009; 201: 194. e1-194.e10.

25. Traen K, Hølund B, Mogensen O. Accuracy of preoperative tumor grade and intraoperative gross examination of myometrial invasion in patients with endometrial cancer. Acta Obstet Gynecol Scand 2007; 86: 739-41. [CrossRef]

26. Maneschi F, Nardi S, Sarno M, Manicone AM, Perugini A, Partenzi A. Endometrial carcinoma: intraoperative evaluation of myometrial invasion. A prospective study. Minerva Ginecol 2008; 60: 267-72.

27. Frumovitz M, Slomovitz BM, Singh DK, Broaddus RR, Abrams J, Sun $\mathrm{CC}$, et al. Frozen section analyses as predictors of lymphatic spread in patients with early-stage uterine cancer. J Am Coll Surg 2004; 199: 388-93. [CrossRef]

28. Kucera E, Kainz C, Reinthaller A, Sliutz G, Leodolter S, Kucera H, et al. Accuracy of intraoperative frozen-section diagnosis in stage I endometrial adenocarcinoma. Gynecol Obstet Invest 2000; 49: 62-6. [CrossRef]

29. Zorlu CG, Kuscu E, Ergun Y, Aydogdu T, Cobanoglu O, Erdas O. Intraoperative evaluation of prognostic factors in stage I endometrial cancer by frozen section: how reliable? Acta Obstet Gynecol Scand 1993; 72: 382-5. [CrossRef]

30. Kayikçioğlu F, Boran N, Meydanli MM, Tulunay G, Köse FM, Bülbül D. Is frozen-section diagnosis a reliable guide in surgical treatment of stage I endometrial carcinoma? Acta Oncol 2002; 41: 444-6. [CrossRef]

31. Attard MS, Coutts M, Devaja O, Summers J, Jyothirmayi R, Papadopoulos A. Accuracy of frozen section diagnosis at surgery in pre- malignant and malignant lesions of the endometrium. Eur $\mathrm{J}$ Gynaecol Oncol 2008; 29: 435-40.
32. Quinlivan JA, Petersen RW, Nicklin JL. Accuracy of frozen section for the operative management of endometrial cancer. BJOG 2001; 108:798-803. [CrossRef]

33. Case AS, Rocconi RP, Straughn JM Jr, Conner M, Novak L, Wang W, et al. A prospective blinded evaluation of the accuracy of frozen section for the surgical management of endometrial cancer. Obstet Gynecol 2006; 108: 1375-9. [CrossRef]

34. Turan T, Oguz E, Unlubilgin E, Tulunay G, Boran N, Demir OF, et al. Accuracy of frozen-section examination for myometrial invasion and grade in endometrial cancer. Eur J Obstet Gynecol Reprod Biol 2012; 167: 90-5 [CrossRef]

35. Everett E, Tamimi H, Greer B, Swisher E, Paley P, Mandel L, et al. The effect of body mass index on clinical/pathologic features, surgical morbidity, and outcome in patients with endometrial cancer. Gynecol Oncol 2003; 90: 150-7. [CrossRef]

36. Lee JY, Jung DC, Park SH, Lim MC, Seo SS, Park SY, et al. Preoperative Prediction Model of Lymph Node Metastasis in Endometrial Cancer. Int J Gynecol Cancer 2010; 20: 1350-5

37. Creasman WT, Morrow CP, Bundy BN, et al. Surgical pathologic spread patterns of endometrial cancer: a Gynecologic Oncology Group study. Cancer 1987; 60: 2035-41. [CrossRef]

38. Sanjuán A, Cobo T, Pahisa J, Escaramís G, Ordi J, Ayuso JR, et al. Preoperative and intraoperative assessment of myometrial invasion and histologic grade in endometrial cancer: role of magnetic resonance imaging and frozen section. Int J Gynecol Cancer 2006; 16: 385-90. [CrossRef]

39. Neubauer NL, Havrilesky LJ, Calingaert B, Bulusu A, Bernardini $\mathrm{MQ}$, Fleming ND, et al. The role of lymphadenectomy in the management of preoperative grade 1 endometrial carcinoma. Gynecol Oncol 2009; 112: 511-6 [CrossRef]

40. Ben-Shachar I, Pavelka J, Cohn DE, Copeland LJ, Ramirez N, Manolitsas T, et al. Surgical staging for patients presenting with grade 1 endometrial carcinoma. Obstet Gynecol 2005; 105: 487-93. [CrossRef]

41. Ugaki H, Kimura T, Miyatake T, Ueda Y, Yoshino K, Matsuzaki S, et al. Intraoperative frozen section assessment of myometrial invasion and histology of endometrial cancer using the revised FIGO staging system. Int J Gynecol Cancer 2011; 21: 1180-4.

42. Case AS, Rocconi RP, Straughn JM Jr, Conner M, Novak L, Wang W, et al. A prospective blinded evaluation of the accuracy of frozen section for the surgical management of endometrialcancer. Obstet Gynecol 2006; 108: 1375-9. [CrossRef]

43. Fanning J, Tsukada Y, Piver MS. Intraoperative frozen section diagnosis of depth of myometrial invasion in endometrial adenocarcinoma. Gynecol Oncol 1990; 37: 47-50. [CrossRef]

44. Roland PY, Kelly FJ, Kulwicki CY, Blitzer P, Curcio M, Orr JW Jr. The benefits of a gynecologic oncologist: a pattern of care study for endometrial cancer treatment. Gynecol Oncol 2004; 93: 125-30. [CrossRef] 